\title{
KEDUDUKAN PEMERINTAH PUSAT DALAM TARAF SINKRONISASI \\ DAN HARMONISASI PERATURAN TERKAIT PENGATURAN \\ ANGKUTAN NON-UMUM BERBASIS ONLINE SESUAI DENGAN KEADILAN PANCASILA
}

\author{
Emut Suharsono \\ Mahasiswa Program Studi Magister Hukum \\ Universitas Semarang
}

\begin{abstract}
ABSTRAK
transportasi online ini belum ada payung hukum yang jelas, sehingga menimbulkan pro dan kontra. Aturan yang ada masih tumpang tindih, sehingga pemerintah pusat perlu melakukan sinkronisasi dan harmonisasi peraturan terkait angkutan non-umum berbasis online ini. Adapun perumusan masalah dalam penelitian ini adalah upaya, problematika dan solusi pemerintah pusat dalam melakukan taraf sinkronisasi dan harmonisasi peraturan terkait pengaturan angkutan non umum berbasis online sesuai dengan keadilan Pancasila. Tujuan penelitian ini adalah untuk memahami, mendeskripsikan dan menelaah mengenai upaya, problematika dan solusi pemerintah pusat dalam taraf sinkronisasi dan harmonisasi peraturan terkait pengaturan angkutan non-umum berbasis online sesuai dengan keadilan Pancasila.

Penelitian ini menggunakan pendekatan yuridis normatif, yang bersifat deskriptif analisis, dengan data yang digunakan adalah data sekunder, yakni melalui studi kepustakaan, yang kemudian dianalisa secara kualitatif, dengan menggunakan teori negara hukum, teori legislasi, dan teori keadilan.

Hasil penelitian menunjukkan bahwa : (1) upaya yang dilakukan pemerintah dalam taraf sinkronisasi dan harmonisasi peraturan terkait pengaturan angkutan umum berbasis online yang memiliki kewenangan di bidang legislasi, selama ini hanya dengan melakukan revisi dan mencabut peraturan yang mengatur angkutan non-umum berbasis online, (2) Problematikanya karena peraturan belum dapat berlaku secara efektif, belum memberikan kepastian hukum, dan belum dapat mewujudkan tujuan hukum. Solusi yang dapat dilakukan adalah : (a) tidak tergesa-gesa dalam menerbitkan peraturan; (b) mengeluarkan peraturan yang dapat dilaksanakan oleh pihak terkait; (c) mengedepankan kepentingan masyarakat; (d) mendasarkan pada asas musyawarah mufakat; serta (e) pengaturan ojek online melalui peraturan daerah. Peran serta masyarakat juga sangat penting untuk mewujudkan peraturan yang bernilai keadilan berdasarkan Pancasila.
\end{abstract}

Kata Kunci : Pemerintah, Harmonisasi, Sinkronisasi, Peraturan, Angkutan 


\begin{abstract}
Online transportation has no clear legal protection, so that it raises the pros and cons in the middle of the community. The existing rules are still overlapping, so the central government needs to synchronize and harmonize the regulations related to online-based non-public transport. The formulation of the problem in this study is the efforts, problems and solutions of the central government in conducting the level of synchronization and harmonization of regulations related to the regulation of online-based non-public transport in accordance with Pancasila's justice values. The purpose of this study was to understand, to describe and to examine the efforts, problems and solutions of the central government in the level of synchronization and harmonization of regulations related to the online-based non-public transport in accordance with Pancasila's justice values.

This study used a normative juridical approach, which is descriptive in nature of analysis, with the data used were secondary data, namely through library studies. The data were analyzed qualitatively by using the theory of state law, legislation theory, and the theory of justice.

The results showed that: (1) efforts made by the government in the level of synchronization and harmonization of regulations related to the regulation of online-based public transport has authority in the field of legislation, so far it is done by revising and revoking regulations governing online-based non-public transport, (2) The policy and regulations have not been able to apply effectively, have not provided legal certainty, and have not been able to realize legal objectives. The solutions that can be done are: (a) in no hurry in issuing regulations; (b) issue regulations that can be carried out by related parties; (c) prioritizing the interests of the community; (d) based on the principle of deliberation and consensus; and (e) online motorcycle taxi regulations is done through regional regulations. The role of the community is also very important in realizing regulations that contain Pancasila's justice values.
\end{abstract}

Keywords: Government, Harmonization, Synchronization, Regulations, Transportation 


\section{PENDAHULUAN}

Penyelenggaraan pelayanan publik merupakan salah satu upaya dari pemerintah demi terwujudnya kesejahteraan rakyat. Pelayanan publik adalah salah satu konsep untuk mencapai apa yang dikehendaki oleh masyarakat dan negara. Salah satu bentuk pelayanan publik bagi masyarakat adalah penyelenggaraan sarana dan prasarana publik, yakni alat transportasi. Kemudahan dan ketepatan waktu adalah hal yang diinginkan oleh masyarakat dalam memperoleh pelayanan di bidang transportasi. Akan tetapi, kemudahan dan ketepatan waktu tersebut selama ini sulit untuk didapatkan masyarakat, yang salah satunya dikarenakan masalah kemacetan lalu lintas dan jauhnya jarak yang ditempuh dengan menggunakan alat transportasi umum yang disediakan oleh pemerintah maupun perusahaan jasa angkutan yang tidak langsung melewati jalan yang dituju.

Kehidupan masyarakat yang selalu bergerak (dinamis) dan selalu mengalami perubahan, menuntut adanya inovasi yang lebih baik terhadap jasa transportasi publik. Terlebih di era globalisasi ini, yang ditandai dengan perkembangan ilmu pengetahuan dan teknologi, memaksa masyakat dan negara untuk mengikuti perubahan tersebut.

Bukan hal yang mudah bagi bangsa dan negara untuk mengikuti perubahan global. Apabila tidak mengikuti perubahan tersebut, maka bangsa Indonesia akan tertinggal dari negara lain, terlebih negara Indonesia adalah negara yang berkembang dan masih melakukan pembangunan secara terus-menerus disegala bidang. Apabila dengan mudahnya terbawa arus, maka bangsa Indonesia akan terpengaruh pula pada hal-hal negatif yang melekat pada globalisasi.

Perkembangan kemajuan teknologi dewasa ini membawa perubahan pola hidup manusia dalam bergaul, bersosialisasi, bahkan melakukan aktifitas ekonomi dalam skala lokal, regional, maupun global. Para pengamat sosial memberikan komentar bahwa teknologi digital membawa manusia pada sosok manusia tanpa jiwa, artinya semakin kehilangan kesempatan untuk berinteraksi secara sosial karena semakin banyak waktu dihabiskan di depan internet, televisi, dan media lainnya. Mengikuti perkembangan teknologi, khususnya di bidang teknologi informasi dan komunikasi ICT (Information and Communication Technology) menimbulkan berbagai ekses, baik yang sifatnya positif maupun negatif sehingga dunia hukum ditantang untuk melakukan regulasi, investigasi, sampai menentukan penalty system berdasarkan keadilan dan kepastian hukum. ${ }^{1}$

1 Miftah Thoha, Birokrasi Pemerintah Dan Kekuasaan Di Indonesia, Cetak- 
Kemajuan ilmu pengetahuan dan teknologi yang dimanfaatkan oleh masyarakat, salah satunya adalah internet. Internet membuat jarak menjadi dekat, dan seperti tidak ada batas antar negara. Sangat mudah bagi masyarakat untuk mengetahui informasiinformasi yang terjadi di belahan dunia manapun. Kemudahan juga diperoleh dengan menggunakan teknologi internet saat ini, untuk melakukan transaksi jual-beli, transfer uang, bahkan teknologi ini dimanfaatkan untuk menyediakan jasa transportasi secara online.

Fenomena transportasi online atau angkutan non umum berbasis online merupakan fenomena yang dapat dikatakan terbilang baru dalam perkembangan dunia transportasi dan komunikasi di seluruh dunia pada umumnya dan di Indonesia pada khususnya. Transportasi online ini penggunaannya tidak terlepas dari teknologi internet melalui telepon seluler atau handphone. IImu pengetahuan dan teknologi semakin maju dan mempermudah kehidupan masyarakat dengan berkembangnya inovasi, terutama dalam moda transportasi.

Salah satu contoh inovasi terbaru dalam bidang transportasi darat dengan menggunakan teknologi internet di Indonesia adalah Go-Jek, selain itu ada pula Grab yang sama-sama meramaikan bisnis jasa transportasi atau angkutan non umum berbasis online. Dalam menjalankan usahanya, sebagai perusahaan jasa transportasi online, Go-Jek bermitra

an Pertama, (Yogyakarta : Thafa Media, 2012), hlm. 81. dengan para pengendara sepeda motor (driver), yang sekarang juga dapat menggunakan mobil pribadi sebagai alat transportasi dengan menggunakan aplikasi jasa transportasi online.

Adanya jasa transportasi online ini, memberikan kemudahan bagi masyarakat untuk mendapatkan pelayanan di bidang transportasi ini. Selain, ketepatan waktu, singkatnya jarak, dan biaya yang murah menjadi alasan jasa transportasi online lebih diminati daripada jasa transportasi atau angkutan umum yang konvensional, seperti bus, angkutan kota, dan sebagainya.

Banyak permasalahan yang mewarnai kehadiran angkutan non umum berbasis online ini. Kelemahan dalam sisi substansi hukum, bahwa angkutan non umum berbasis online ini memang tidak dikenal di dalam Undang-Undang Nomor 22 Tahun 2009 tentang Lalu Lintas dan Angkutan Jalan dan Peraturan Pemerintah Nomor 74 Tahun 2014 tentang Angkutan Jalan.

Di sisi lain, adanya perusahaan penyedia jasa angkutan non umum berbasis online ini dapat menambah lapangan pekerjaan dan mengurangi pengangguran. Sebagai negara hukum dan negara kesejahteraan, maka sudah seharusnya negara memberikan akses bagi angkutan non umum berbasis online untuk tetap beroperasi dengan persyaratan yang mudah dipenuhi oleh perusahaan jasa transportasi online maupun mitranya. Permasalahan terbesar di sini adalah upaya untuk membuat sesuatu yang ilegal menjadi legal. 
Tugas pemerintah tidaklah mudah. Di satu sisi pemerintah sebagai pelaksana undang-undang (menjalankan fungsi eksekutif), tetapi juga dituntut untuk mewujudkan kesejahteraan rakyatnya. Salah satu tiang utama dalam penyelenggaraan pemerintahan suatu negara adalah pembentukan peraturan perundang-undangan yang baik, harmonis, dan mudah diterapkan dalam masyarakat. ${ }^{2}$

Diperlukan peraturan yang mengakomodir semua kepentingan para pihak, dan tidak bertentangan dengan peraturan lainnya. Terkait dengan keberadaan angkutan non umum berbasis online seperti penggunaan sepeda motor dan mobil pribadi yang digunakan sebagai angkutan non umum, tidak terdapat pasal yang mengatur mengenai hal tersebut, sehingga keberadaan angkutan non umum yang menggunakan sepeda motor atau mobil dianggap ilegal dan tidak sesuai dengan peraturan, bukan masalah mengenai penggunaan teknologi internetnya yang digunakan untuk menjalankan usaha transportasi jalan online. Banyak manfaat dari adanya keberadaan angkutan non umum berbasis internet, oleh karena itu diperlukan peraturan yang tidak hanya dapat melegalkan keberadaan angkutan non umum berbasis online, akan tetapi juga memberikan perlindungan hukum bagi para pihak, yakni perusahaan jasa angkutan konvesional, perusahaan jasa angkutan berbasis

2 Maria Farida Indrati S., IImu Perundang-Undangan 2, Proses dan Teknik Pembentukkannya 2, Cetakan Kelimabelas, (Yogyakarta : Kanisius, 2013), hIm. 1. online, mitra perusahaan jasa angkutan (driver), serta masyarakat selaku konsumen.

Pembuatan dan perkembangan hukum atau peraturan yang dibuat secara profesional dan logis, maka akan menghasilkan produk hukum atau peraturan yang dapat mempengaruhi bahkan mengubah sendi-sendi kehidupan masyarakat.

Seluruh peraturan hukum yang dibuat harus sesuai dengan nilai-nilai yang terkandung di dalam Pancasila. Pancasila menjadi sumber dari segala sumber hukum yang menjadi norma dasar bangsa Indonesia dalam membentuk peraturan perundang-undangan, dan Indonesia merupakan negara hukum yang berdasarkan Pancasila. Konsep negara hukum Pancasila merupakan konsep negara hukum Indonesia yang menjadi staatfundamentalnorm bangsa Indonesia. Ciri khas konsep negara hukum Pancasila mengedepankan perlindungan terhadap warga negaranya. $^{3}$

Semua peraturan yang dibuat oleh pemerintah harus sesuai dan tidak boleh bertentangan dengan peraturan yang di atasnya, dan selaras dengan peraturan perundang-undangan lainnya untuk mewujudkan kepastian hukum, kemanfaatan dan keadilan. Oleh karena itu, diperlukan harmonisasi dan sinkronisasi hukum dalam peraturan yang mengatur mengenai angkutan non umum berbasis online.

3 Ferry Irawan Febriansyah, Keadilan Berdasarkan Pancasila (Dasar Filosofis dan Ideologis Bangsa), Cetakan Pertama, (Yogyakarta : Deepublish, 2016), hlm. 95. 
Upaya harmonisasi dan sinkronisasi peraturan hukum tersebut harus tetap mengutamakan nilai keadilan, yakni keadilan Pancasila. Dengan demikian, peraturan hukum yang adil akan dapat diterima dan dilaksanakan oleh seluruh komponen bangsa.

\section{Metode Penelitian}

Metode yang akan digunakan dalam penelitian ini terdiri dari langkah-langkah berikut :

1. Metode Pendekatan

Metode pendekatan yang digunakan dalam penelitian hukum ini adalah yuridis normatif, dengan menggunakan pendekatan undang-undang.

2. Spesifikasi Penelitian

Penelitian ini bersifat deskriptif analisis, karena peneliti berkeinginan untuk menggambarkan atau memaparkan atas subjek dan objek penelitian, yang kemudian dianalisa dan akhirnya ditarik kesimpulan dari hasil penelitian tersebut. ${ }^{4}$

3. Jenis Data

Data yang digunakan dalam penelitian ini adalah data sekunder. Data sekunder adalah data yang diperoleh dari bahanbahan pustaka melalui studi kepustakaan. ${ }^{5}$

4. Teknik Pengumpulan Data

Data yang dikumpulkan dalam penelitian ini adalah data

4 Mukti Fajar ND dan Yulianto Achmad, Dualisme Penelitian Hukum Normatif dan Empiris, (Yogyakarta : Pustaka Pelajar, 2010), hlm. 183.

5 Jhonny Ibrahim, Teori dan Metodologi Penelitian Hukum Normatif, (Malang : Bayumedia, 2011), hlm. 392. sekunder yang diperoleh melalui studi kepustakaan.

5. Teknik Analisis Data

Analisis yang dipergunakan dalam penelitian ini adalah analisis kualitatif, yaitu suatu tata cara penelitian yang menghasilkan data deskriptif analitis, yaitu apa yang diperoleh dari penelitian kepustakaan atau dinyatakan oleh narasumber secara tertulis atau lisan dan juga perilakunya yang nyata, yang diteliti dan dipelajari sebagai sesuatu yang utuh. ${ }^{6}$

\section{Pembahasan}

1. Upaya yang dilakukan pemerintah dalam taraf sinkronisasi harmonisasi peraturan terkait pengaturan angkutan umum berbasis online;

A. Hamid S. Attamimi mengatakan bahwa dalam abad ke-20 ini hampir tidak satu negara pun yang menganggap sebagai negara modern tanpa menyebutkan dirinya negara berdasarkan atas hukum. ${ }^{7}$

Pelaksanaan Pasal 1 ayat (3) Undang-Undang Dasar Negara Republik Indonesia Tahun 1945 bahwa negara Indonesia adalah negara hukum, maka tidak boleh ada penyimpangan dari undang-undang yang berlaku.

Undang-Undang Dasar Negara Republik Indonesia

${ }^{6}$ Soerjono Soekanto, Pengantar Penelitian Hukum, (Jakarta : Universitas Indonesia Press, 1986), hlm. 250.

7 Yopie Morya Immanuel Patiro, Diskresi Pejabat Publik dan Tindak Pidana Korupsi, Cetakan Pertama, (Bandung : Keni Media, 2012), hlm. 7. 
Tahun 1945 merupakan hukum dasar negara yang menempati posisi sebagai hukum negara tertinggi dalam tertib hukum (legal order) Indonesia. Di bawah Undang-Undang Dasar Negara Republik Indonesia Tahun 1945 terdapat berbagai aturan hukum/perundangundangan yang bersumber dan berdasarkan pada UndangUndang Dasar Negara Republik Indonesia Tahun $1945 .{ }^{8}$

Peraturan perundangundangan di Indonesia tidak boleh bertentangan dengan peraturan yang berada di tingkat lebih tinggi. Peraturan perundang-undangan memiliki tingkatan yang diatur di dalam Pasal 7 ayat (1) UndangUndang Nomor 12 Tahun 2011. Sebagai suatu negara hukum yang bertujuan mewujudkan kesejahteraan umum, maka setiap kegiatan yang dilaksanakan harus diorientasikan pada tujuan yang hendak dicapai dan berdasarkan pada hukum yang berlaku sebagai aturan kegiatan kenegaraan, pemerintahan, dan kemasyarakatan.

Bagi negara Indonesia yang tetap komitmen dengan bentuk negara kesejahteraan sebagaimana yang terbukti dengan adanya amandemen Pasal 33 Undang-Undang Dasar Tahun 1945 dengan menambah dua ayat yang semula 3 ayat

8 Ukti BA, Negara Hukum Indonesia, diakses dalam http://uktibin tiarifah.blog spot.co.id/2016/01/normal-0false-false-false-in-x-none-x.html, pada tanggal 6 Agustus 2018, waktu : 20.51 WIB. menjadi 5 ayat. Dengan ditambahkannya 2 ayat tersebut, sistem kesejahteraan khususnya dalam bidang ekonomi menerima sisi positif dari sistem liberalis dan sosialis, tetapi tetap menolak pandangan fundamentalisme pasar (market-funda mentalism). ${ }^{9}$

Sudah menjadi tugas pemerintah dalam negara hukum modern selain menyediakan lapangan pekerjaan dan memberikan pengaturan terhadap segala hal yang belum daitur dalam peraturan perundang-undangan.

Fenomena yang terjadi saat ini adalah adanya transportasi berbasis online. $\mathrm{Di}$ Indonesia marak bermunculan aplikasi transportasi berbasis online, yang mana tujuan aplikasi ini dimaksudkan untuk memudahkan para penggunanya dalam mengakses media transportasi yang akan digunakan dalam mobilitas sehari-hari. Aplikasi transportasi berbasis online, di antaranya UberTaxi, kemudian diikuti dengan munculnya Gojek, Grab Bike, GrabTaxi, dan aplikasi berbasis online lainnya. Aplikasi tersebut sekarang menjadi bisnis layanan transportasi berbasis online.

Sebagaimana disebutkan

di dalam Pasal 7 ayat

${ }^{9}$ Djauhari, Politik Hukum Negara Kesejahteraan Indonesia, Studi Tentang Kebijakan Regulasi dan Institusionalisasi Gagasan Kesejahteraan Sosial Ekonomi Masyarakat Nelayan di Jawa Tengah, Cetakan Kesatu, (Semarang : Unissula Press, 2008), hlm. 145. 
Undang-Undang Nomor 22 Tahun 2009 tentang Lalu Lintas dan Angkutan Jalan, yang menyatakan bahwa : "Penyelenggaraan Lalu Lintas dan Angkutan Jalan dalam kegiatan pelayanan langsung kepada masyarakat dilakukan oleh Pemerintah, Pemerintah Daerah, badan hukum, dan/atau masyarakat".

Fenomena aplikasi berbasis online ini tidak terlepas dari pro dan kontra dalam masyarakat. Banyak kontra yang hadir bagi aplikasi berbasis online, terutama dari kalangan moda transportasi konvensional serta dari pihak pemerintah sebagai pembuat kebijakan. Sesuai dengan hukum ekonomi bahwa ketika permintaan atas suatu barang atau jasa meningkat dan terus ada, maka penawaran akan barang atau jasa tersebut pun akan tetap ada.

Aplikasi transportasi berbasis online terganjal beberapa masalah, akan tetapi permintaan akan transportasi berbasis online terus ada dan meningkat, hal ini tidak seketika akan menghentikan beroperasinya aplikasi transportasi berbasis online. Saat ini, di Indonesia fenomena transportasi berbasis online terganjal dalam hal regulasi dan kejelasan payung hukum yang mengatur tentang transportasi umum. Fenomena transportasi berbasis online ini harusnya dapat disikapi sebijak mungkin dan dapat dengan segera diberikan payung hukum yang jelas karena tidak dapat dipungkiri bahwa transportasi online ini dapat membuka lapangan pekerjaan bagi siapapun yang berminat menjadi driver dan dapat mengangkat pendapatan driveryang bergabung.

Kemajuan teknologi dapat memperbaiki sistem transportasi menjadi lebih baik yang memudahkan akses bagi para penggunanya. Setiap perubahan yang terjadi di masyarakat, pasti akan menimbulkan pro dan kontra. Ada pihak yang mendukung, dan ada pula pihak yang tidak mendukung. Akan tetapi, dilihat dari sisi manfaat yang diperoleh maka transportasi berbasis online adalah suatu perubahan atau dinamika dalam masyarakat yang harus diperhatikan dan disikapi dengan payung hukum yang tepat, yang dapat memberikan kepastian hukum, kemanfaatan dan keadilan bagi semua pihak.

Payung hukum yang pasti

bagi pengaturan transportasi berbasis online akan memberikan tidak hanya perlindungan bagi perusahaan jasa transportasi online dan bagi driver yang bekerja di perusahaan tersebut. Selain itu, juga bagi masyarakat selaku konsumen, yang akhir-akhir ini marak kejahatan yang dilakukan oleh oknum driver yang merugikan konsumen yang melakukan perampokan hingga pembunuhan pada konsumennya.

Sebagaimana diketahui mengenai transportasi berbasis online ini tidak diatur di dalam Undang-Undang Nomor 22 
Tahun 2009 dan peraturan pelaksanaannya, sehingga keberadaan transportasi berbasis online dianggap ilegal karena tidak terdapat aturan yang mengaturnya. Jika transportasi berbasis online dilegalkan, maka tentunya akan bertentangan dengan Undang-Undang Nomor 22 Tahun 2009.

Di sinilah peran penting pemerintah pusat dalam melakukan taraf sinkronisasi dan harmonisasi peraturan terkait pengaturan angkutan non-umum berbasis online. Peran penting pemerintah ini sebagai pelaksanaan dari perwujudan negara hukum modern atau negara kesejahteraan.

Masalah transportasi berbasis online ini memerlukan penanganan yang serius, sehingga pemerintah perlu melakukan upaya untuk melakukan sinkronisasi dan harmonisasi terkait peraturan yang mengatur mengenai transportasi berbasis online dengan kewenangan yang dimiliki oleh pemerintah.

Pemerintah pusat dalam upayanya melakukan sinkronisasi dan harmonisasi peraturan terkait dengan angkutan nonumum berbasis online, maka pemerintah dapat menyesuaikan peraturan-peraturan yang diadakan pembuat undangundang pusat dengan keadaan yang sungguh-sungguh terjadi di masyarakat.

Dalam fungsinya sebagai perlindungan kepentingan manusia, maka hukum mempunyai sasaran atau tujuan yang hendak dicapai.. Adapun tujuan pokok hukum adalah untuk menciptakan tatanan masyarakat yang tertib atau menciptakan ketertiban dan keseimbangan. Dengan tercapainya ketertiban di dalam masyarakat diharapkan kepentingan manusia akan terlindungi. Dalam mencapai tujuannya itu hukum bertugas membagi hak dan kewajiban antar perorangan di dalam masyarakat, membagi wewenang dan mengatur cara memecahkan masalah hukum serta memelihara kepastian hukum. ${ }^{10}$

Hukum sebagai landasan yuridis bagi penyelenggara negara dan masyarakat dalam melakukan tindakan atau perbuatan agar interaksi antara pemerintah dengan warga masyarakat dapat berjalan dengan tertib, aman dan lancar, karena hukum pada hakekatnya dibuat dan diberlakukan untuk mengatur tata kehidupan dalam masyarakat. Bila hukum tidak ditempatkan sebagai landasan yuridis dalam bertindak dalam suatu negara, maka suasana kehidupan dalam masyarakat tentu akan menjadi kacau bahkan bisa terjadi konflik di antara mereka. ${ }^{11}$

Keberadaan hukum sangat penting dalam mengatur segala hal yang terjadi di dalam

10 Edi Setiadi dan Rena Yulia, Hukum Pidana Ekonomi, Edisi Pertama, Cetakan Pertama, (Yogyakarta : Graha Ilmu, 2010), hlm. 7.

11 Jawade Hafidz Arsyad dan Dian Karisma, Sentralisasi Birokrasi Pengadaan Barang \& Jasa Pemerintah, Cetakan Pertama, (Jakarta : Sinar Grafika, 2018), hlm. 25. 
masyarakat, termasuk fenomena transportasi online. Telah jelas bahwa sebelumnya, transportasi online belum ada payung hukumnya, dan keberadaan transportasi online ini tidak diatur dalam perundangundangan. Akan tetapi, keberadaannya memberikan manfaat bagi masyarakat. Sebagaimana disebutkan bahwa dalam konsepsi negara hukum modern, kepada pemerintah diberikan kewenangan legislasi. Kewenangan legislasi ini adalah kewenangan untuk membuat dan menggunakan peraturan perundang-undangan.

Walaupun pemerintah berwenang menetapkan peraturan perundang-undangan, namun kewenangan tersebut harus didasarkan atas pendelegasian kewenangan yang berasal dari pembentuk undangundang (legislative delegation of the rule-making power). Dengan perkataan lain, Dewan Perwakilan Rakyat adalah pembentuk undang-undang, sedangkan presiden merupakan pelaksana undang-undang tersebut, presiden atau pemerintah harus membuat peraturan perundang-undangan di bawah undang-undang sebagai "subordinate legislations", maka peraturan dimaksud haruslah merupakan "delegated legislations" ataupun "subdelegated legislations". Dalam hal demikian, pejabat atau lembagalembaga regulator yang menjalankan undang-undang itu dapat juga disebut sebagai "subsidiary legislator", "sub- ordinate legislator", "delegated legislator", ataupun "secondary legislator". ${ }^{12}$

Dari uraian tersebut maka tingkatan hierarkis peraturan perundang-undangan yang dibentuk oleh pejabat-pejabat ini berada di bawah tingkatan undang-undang yang merupakan "legislative acts" atau produk legislatif, sedangkan produk hukum yang dibentuk oleh lembaga-lembaga sekunder ini sebagai pejabat atau lembaga eksekutif biasa disebut pula dengan istilah "executive acts" atau produk eksekutif. ${ }^{13}$

Dengan sifat norma seperti itu, hal penting yang harus diperhatikan dalam penyelenggaraan pemerintahan adalah sinkronisasi norma hukum administrasi secara vertikal, melalui sistem hirarki, dan sinkronisasi serta harmonisasi secara horizontal. Sinkronisasi norma hukum administrasi secara vertikal diperlukan agar norma peraturan perundang-undangan tingkat lebih rendah tidak bertentangan dengan norma peraturan perundang-undangan yang lebih tinggi. Sedangkan sinkronisasi dan harmonisasi secara horizontal diperlukan agar tidak terjadi tumpang tindih (overlapping)

12 Mukhlis Taib, Dinamika Perundang-Undangan Di Indonesia, Cetakan Kesatu, (Bandung : Refika Aditama, 2017), hlm. 114 dan 115.

${ }^{13}$ Ridwan HR, Hukum Administrasi Negara, Hukum Administrasi Negara, Edisi Pertama, Cetakan Kesatu, (Jakarta : Raja Grafindo Persada, 2006), hlm. 143. 
norma Hukum Administrasi antar instansi pemerintahan.

Sinkronisasi dan harmonisasi vertikal dan horizontal norma hukum administrasi menjadi sangat penting, bukan saja untuk kepastian hukum (rechtszekkerheid) bagi para pelaksana urusan pemerintahan dan bagi warga negara, tetapi juga untuk terselenggaranya pemerintahan yang efektif dan efisien. Di samping itu, juga penting dalam rangka kemudahan penentuan pertanggungjawaban hukum dalam penyelenggaraan pemerintahan.

Sinkronisasi peraturan perundang-undangan sering menimbulkan pertentangan mengenai peraturan perundangundangan yang mana yang lebih tepat untuk digunakan untuk kasus tertentu, seperti masalah angkutan non-umum berbasis online. Begitu pula dalam hal harmonisasi peraturan yang terkait dengan transportasi berbasis online.

Transportasi online dengan segala kemudahannya memang masih menyisakan masalah hukum. Belum adanya aturan atau payung hukum yang jelas, sehingga seringkali menjadikan transportasi online sebagai sesuatu yang dianggap ilegal. Lambatnya pemerintah dalam menyediakan payung hukum menjadi penyebab munculnya permasalahan terkait transportasi berbasis aplikasi online.

Upaya pemerintah untuk mengatasi hal tersebut, kemudian diterbitkan Peraturan
Menteri Perhubungan Nomor 32 Tahun 2016 tentang Penyelenggaraaan Angkutan Orang Dengan Kendaraan Bermotor Umum Tidak Dalam Trayek. Selanjutnya, Peraturan Menteri Perhubungan Nomor 32 Tahun 2016 dilakukan revisi.

Peraturan Menteri Perhubungan Nomor 32 Tahun 2016 direvisi dengan diterbitkannya Peraturan Menteri Perhubungan Nomor 26 Tahun 2017 tentang Penyelenggaraan Angkutan Orang Dengan Kendaraan Bermotor Umum Tidak Dalam Trayek. Tapi kemudian, Peraturan Menteri Perhubungan Nomor 26 Tahun 2017 digugat enam pengemudi taksi online lewat perkara Tata Usaha Negara di Mahkamah Agung. Mahkamah Agung mengabulkan gugatan dengan mencabut 18 pasal dalam Peraturan Menteri Perhubungan Nomor 26 Tahun 2017. Majelis menilai peraturan itu bertentangan dengan aturan yang lebih tinggi.

Untuk mengisi kekosongan hukum, pemerintah telah menetapkan Peraturan Menteri Perhubungan (Permenhub) Nomor 108 Tahun 2017 tentang Penyelenggaraan Angkutan Orang Dengan Kendaraan Bermotor Umum Tidak Dalam Trayek. Peraturan Menteri Perhubungan Nomor 108 Tahun 2017 ini aturan yang menjadi payung hukum yang kuat bagi keberadaan taksi online. Akan tetapi, tidak untuk ojek online, yakni angkutan orang dengan menggunakan kendaraan bermotor roda dua. 


\begin{abstract}
Peraturan Menteri Perhubungan Nomor 108 Tahun 2017 dikeluarkan pemerintah agar bisa memastikan pelayanan angkutan orang yang ada saat ini selamat, aman, nyaman, tertib, lancar, dan terjangkau. Dalam kaitannya untuk mewujudkan negara kesejahteraan, maka peraturan ini terkait dengan iklim usaha dikeluarkan demi mendorong pertumbuhan perekonomian nasional berdasarkan demokrasi ekonomi yang berkeadilan dan prinsip pemberdayaan usaha mikro, kecil, dan menengah.
\end{abstract}

Dapat disimpulkan bahwa terkait dengan pengaturan angkutan non-umum berbasis online ini, upaya sinkronisasi dan harmonisasi peraturan yang dilakukan oleh pemerintah pusat adalah dengan melakukan revisi dan mencabut peraturan pelaksanaan dari Undang-Undang Nomor 22 Tahun 2009 untuk melegalkan angkutan nonumum berbasis online, yakni Keputusan Menteri Perhubungan Nomor : UM.302/1/ 21/Phb/ 2015, Peraturan Menteri Perhubungan Nomor 32 Tahun 2016, Peraturan Menteri Perhubungan Nomor 26 Tahun 2017, dan terakhir dengan menerbitkan Peraturan Menteri Perhubungan Nomor 108 Tahun 2017.

Revisi dan pencabutan terhadap peraturan menteri tersebut dikarenakan masih terdapat beberapa pasal yang bertentangan dengan UndangUndang Nomor 22 Tahun 2009 dan Undang-Undang Nomor
Undang-Undang Nomor 20

Tahun 2008.

Mengenai pengaturan

atau letak/posisi harmonisasi

dan sinkronisasi dalam pembentukan peraturan perundangundangan maupun peraturan perundang-undangan yang dibentuk oleh lembaga eksekutif (pemerintah), berdasarkan Undang-Undang Nomor 12 Tahun 2011 belum baku dan jelas, belum memuat aspekaspek pengaturan yang seharusnya diharmoniskan pada suatu rancangan peraturan perundang-undangan maupun perundang-undangan yang telah diterbitkan, oleh karena tidak diatur secara rinci atau mendetail dalam suatu bab yang mengatur secara khusus tentang harmonisasi peraturan perundang-undangan. Hal tersebut dapat dilihat dari dalam bab-bab Undang-Undang Nomor 12 Tahun 2011 tersebut yang tidak memuat pengaturan lebih luas dan mendalam mengenai harmonisasi dan sinkronisasi.

Pada dasarnya, selama tidak terjadi masalah dari pelaksanaan peraturan perundangundangan, maka penyelenggara negara (eksekutif) tidak merasa memerlukan adanya suatu pengharmonisasian dan sinkronisasi hukum (peraturan perundang-undangan). Masalah baru dirasakan oleh penyelenggara negara apabila dalam pelaksanaan perundang-undang an menemui kesulitan. Misalnya telah terjadi duplikasi antara peraturan perundang-undangan 
yang sederajat satu sama lain atau pertentangan dari sisi hierarki peraturan perundangundangan. Atas penjelasan tersebut tidak heran bahwa pihak yang dirugikan sebenarnya ialah masyarakat itu sendiri sebagai pihak yang paling berkepentingan dengan pembentukan peraturan perundangundangan tersebut. ${ }^{14}$

2. Problematika dan solusi atau upaya pemerintah pusat dalam taraf sinkronisasi dan harmonisasi peraturan terkait pengaturan angkutan non-umum berbasis online sesuai dengan keadilan Pancasila.

Perubahan dalam masyarakat seperti adanya keberadaan angkutan non-umum berbasis online juga membutuhkan pengaturan hukum berbentuk peraturan perundang-undangan agar apa yang terjadi di dalam masyarakat dapat dikontrol dan ditertibkan agar dapat melindungi kepentingan masyarakat dan tidak ada pihak yang dirugikan.

Peraturan perundangundangan yang dibuat dan mempunyai kekuatan hukum mengikat, dibatasi dan harus berada dalam koridor hukum Negara Kesatuan Republik Indonesia, atau tidak boleh bertentangan atau menyimpang dari peraturan perundangundangan yang lebih tinggi.

14 Direktorat Hukum dan HAM, Kajian Harmonisasi Peraturan PerundangUndangan Dalam Mendukung Pembangunan Nasional, (Jakarta : Kementerian Negara Perencanaan Pembangunan Nasional/Bappenas, 2005), hlm. 4-5.
Keberadaan transportasi berbasis online merupakan suatu bentuk perkembangan dalam dinamika atau kehidupan masyarakat. Selain bermanfaat bagi masyarakat, juga sangat mempengaruhi perekonomian negara. Akan tetapi, peraturan yang dibentuk bagi sebagian masyarakat terkait pengaturan angkutan non-umum berbasis online, kerap kali dilakukan revisi dan pencabutan sebagai bentuk sinkronisasi dan harmonisasi hukum, dan yang terakhir adalah Peraturan Menteri Perhubungan Nomor 108 Tahun 2017 masih terdapat kelemahan, yakni di antaranya :

a. Peraturan Menteri Perhubungan Nomor 108 Tahun 2017 masih ada kelemahan dan dinilai produk cacat hukum. Hal ini karena bila mengacu Undang-Undang Nomor 22 Tahun 2009 sebagai payung hukum, tidak pernah ada istilah kata angkutan sewa khusus;

b. Peraturan Menteri Perhubungan Nomor 108 Tahun 2017 tidak mewajibkan perusahaan aplikasi di sektor transportasi menjadi perusahaan transportasi. Jika demikian, maka negara akan kehilangan potensi pajak yang besar;

c. Ketentuan dalam Peraturan Menteri Perhubungan Nomor 108 Tahun 2017 memberatkan driver taksi online, di antaranya :

1) Aturan mengenai Surat Tanda Nomor Kendaraan 
(STNK) yang harus berbadan hukum;

$$
\text { Aturan ini di- }
$$
anggap menyulitkan, karena mobil yang digunakan untuk taksi online adalah mobil pribadi yang dibeli juga dengan uang pribadi, sehingga nama yang tertera di STNK pun nama pribadi. Sementara Kemenhub menganggap kendaraan yang digunakan untuk mengangkut penumpang umum dan berbayar dikategorikan sebagai angkutan umum. Karena itu mereka harus tunduk pada undangundang yang mengharuskan kendaraan umum memiliki STNK atas nama badan hukum.

2) Harus melakukan KIR; Aturan lain yang dianggap memberatkan adalah diharuskannya kendaraan yang digunakan untuk taksi online mengikuti uji kendaraan bermotor (KIR). Para sopir taksi online menganggap mereka tak perlu melakukan uji KIR karena KIR hanya untuk angkutan umum. Kementerian Perhubungan dalam situs resmi mereka menyatakan KIR perlu dilakukan oleh semua kendaraan yang digunakan untuk mengangkut penumpang dan berbayar. Taksi online diharuskan melakukan uji KIR karena mereka mengangkut penumpang umum dan berbayar.

3) Wajib memiliki minimal lima kendaraan;

Bagi para sopir taksi online, aturan ini jelas sangat memberatkan. Apalagi, selain harus memiliki minimal lima kendaraaan, penyedia jasa angkutan juga diwajibkan memiliki lahan yang bisa menampung kendaraan-kendaraan ter sebut. Akan tetapi, Kementerian Perhubungan menyatakan bahwa sopir taksi online yang memiliki kurang dari lima kendaraan, dapat berhimpun dalam satu badan hukum berbentuk koperasi. Koperasi tersebut harus mempunyai izin sebagai penyelenggara angkutan orang.

4) Diberlakukannya tarif batas bawah dan atas.

Ketentuan lain yang dianggap memberatkan adalah ketentuan tarif batas dan bawah yang akan diberlakukan kepada taksi online. Sebab ketentuan ini dianggap bisa membuat tarif taksi online tidak akan lagi kompetitif, karena tarif sudah ditentukan oleh pengambil kebijakan. Kementerian Perhubungan melalui situs resmi mereka menyebutkan jika tarif bawah dan atas diterap- 
kan untuk melindungi konsumen dan para sopir taksi online itu sendiri. Tarif atas diberlakukan agar penyedia jasa taksi online tidak memberlakukan tarif sewenangwenang pada saat jamjam sibuk. Sementara tarif bawah diberlakukan agar tidak terjadi perang tarif murah yang bisa berimbas buruk pada sopir taksi online.

Mengingat upaya yang dilakukan oleh pemerintah dalam melakukan sinkronisasi dan harmonisasi peraturan terkait pengaturan angkutan nonumum berbasis online hanya dilakukan dengan melakukan revisi dan pencabutan peraturan perundang-undangan setelah adanya uji materiil oleh Mahkamah Agung, hal tersebut tidak efektif karena peraturan angkutan non-umum berbasis online kerap berganti-ganti yang menandakan peraturan tersebut belum dapat berlaku secara efektif dan belum memberikan kepastian hukum. Selain itu, masih adanya demontrasi atau protes terhadap diberlakukannya Peraturan Menteri Perhubungan Nomor 108 Tahun 2017 maka peraturan tersebut belum dapat mewujudkan tujuan hukum yakni keadilan dan memberikan perlindungan hukum bagi para pihak.

Peraturan yang diterbitkan tersebut, pada dasarnya untuk memberikan perlindungan bagi masyarakat, driver bahkan bagi perusahaan transportasi online. Hal ini merupakan bentuk peranan hukum dalam pembangunan. Mengingat penggunaan aplikasi online ini merupakan fenomena yang terjadi dalam perkembangan kehidupan masyarakat. Keberadaan perusahaan transportasi online dapat mendukung usaha pembangunan.

Hukum positif menjamin kepastian hidup, tetapi baru menjadi lengkap bila disusun sesuai dengan prinsip-prinsip keadilan. Demontrasi atau protes yang dilakukan oleh pengemudi angkutan non-umum berbasis online telah membuktikan bahwa peraturan yang diterbitkan oleh pemerintah belum dapat mengakomodasi kepentingan mereka. Masyarakat dipaksa untuk melaksanakan peraturan yang dibuat. Pemerintah tergesa-gesa dalam menerbitkan peraturan tanpa melibatkan pihak-pihak terkait.

Dewasa ini, produk peraturan yang dikeluarkan oleh menteri, lembaga, badan atau pejabat yang diberi wewenang, sering terjadi antara peraturan yang satu dengan yang lain (yang dikeluarkan oleh lembaga itu sendiri dan/atau antara lembaga) muatan materi yang diatur tidak semestinya, tidak sinkron dan tumpang tindih. Kondisi ini dapat terjadi, dikarenakan masing-masing lembaga/pejabat yang mengeluarkan peraturan, memiliki dasar dan mengacu pada undangundang yang menjadi penjurunya, sehingga kebijakannya cenderung lebih didasari ke- 
pentingan sektoral untuk keberhasilan urusan yang menjadi kewenangannya. Hal ini sering menimbulkan ketidakpastian hukum dan menimbulkan masalah di daerah, terutama dalam hubungan koordinasi pelaksanaan otonomi daerah dan tugas pembatuan.

Upaya yang dapat dilakukan oleh pemerintah pusat di dalam melakukan sinkronisasi dan harmonisasi peraturan terkait pengaturan angkutan nonumum berbasis online, yakni :

a. Tidak tergesa-gesa dalam menerbitkan peraturan terkait angkutan non-umum berbasis online;

b. Mengeluarkan peraturan yang dapat dilaksanakan oleh para pihak terkait yang mengatur pihak terkait yang menawarkan pelayanan yang lebih baik, jaminan keamanan perjalanan, harga yang relatif murah dan tepat waktu;

c. Lebih mengedepankan kepentingan masyarakat selaku konsumen dan pengusaha mikro dan kecil dengan konsep sharing economy yang saling menguntungkan dengan mengedepankan asas kekeluargaan sebagaimana amanat Pasal 33 ayat (1) Undang-Undang Dasar Negara Republik Indonesia Tahun 1945;

d. Penyusunan regulasi di bidang transportasi berbasis teknologi dan informasi harus didasarkan pada asas musyawarah mufakat yang melibatkan seluruh stake- holder di bidang jasa transportasi sehingga secara bersama dapat menumbuhkembangkan usaha ekonomi mikro, kecil dan menengah, tanpa meninggalkan asas kekeluargaan atau melibatkan partisipasi masyarakat;

e. Terkait dengan ojek online, maka berdasarkan UndangUndang Nomor 22 Tahun 2009, pengaturannya dapat diserahkan pada pemerintah daerah dengan pembentukan peraturan daerah.

Salah satu usaha untuk mengatasi banyaknya peraturan perundang-undangan yang tumpang tindih dan tidak sinkron antara yang satu dengan yang lain adalah dengan melaksanakan proses perencanaan pembentukan undang-undang. Prolegnas memiliki peranan yang penting dalam pembangunan hukum nasional. Selain instrumen perencanaan pembentukan hukum dengan cara menetapkan prioritas rancangan undangundang yang akan dibahas Dewan Perwakilan Rakyat bersama pemerintah (sebagai instrumen perencanaan), Prolegnas juga berfungsi sebagai potret politik hukum nasional atau isi hukum nasional untuk mencapai tujuan Pancasila dan Undang-Undang Dasar Negara Republik Indonesia Tahun $1945 .^{15}$

${ }^{15}$ Elly Erawati dkk. (Ed), Beberapa Pemikiran Tentang Pembangunan Sistem Hukum Nasional Indonesia Liber Amicorum Untuk Prof. Sunaryati Hartono, S.H., (Bandung : Citra Aditya Bakti, 2011), hlm. 95. 
Terkait dengan hal tersebut, menurut Bagir Manan ada berbagai kenyataan yang perlu dicatat, yaitu : ${ }^{16}$

a. Lebih dari $50 \%$ daftar Prolegnas semata-mata program perubahan undang-undang yang ada, bukan undangundang yang baru;

b. Undang-undang baru lebih banyak berkisar pada undang-undang di bidang politik dan pemerintahan (pemilihan umum, pemilihan presiden dan wakil presiden, kepartaian, dan pemerintahan daerah). Menjadi semacam ritual agar undangundang tersebut selalu diubah untuk menampung berbagai kepentingan politik para pemain kekuasaan. Tidak banyak keinginan untuk mengutamakan undang-undang yang berkaitan dengan kesejahteraan rakyat atau kepentingan rakyat pada umumnya;

c. Mutu undang-undang yang dihasilkan tidak mencerminkan mutu yang baik, sehingga senantiasa menjadi objek perkara di Mahkamah Konstitusi;

d. Tidak jarang terjadi inkonsistensi, bahkan pertentangan antara berbagai undangundang, yang pada gilirannya menyulitkan para penegak hukum.

Peran serta masyarakat sangat diperlukan di dalam harmonisasi dan sinkronisasi

${ }^{16}$ Ibid., hlm. 110. sebuah peraturan. Pasal 120 ayat (1) Peraturan Pemerintah Nomor 74 Tahun 2014 tentang Angkutan Jalan menyatakan bahwa masyarakat berhak untuk berperan serta dalam penyelenggaraan angkutan jalan. Sebagaimana penjelasan atas konsiderans Undang-Undang Nomor 22 Tahun 2009 berdasar pada semangat bahwa penyelenggaraan lalu lintas dan angkutan jalan yang bersifat lintas sektor harus dilaksanakan secara terkoordinasi oleh para pembina beserta para pemangku kepentingan (stakeholders) lainnya.

Guna mengatasi permasalahan yang sangat kompleks, Undang-Undang Nomor 22 Tahun 2009 mengamanatkan dibentuknya forum lalu lintas dan angkutan jalan. Forum lalu lintas dan angkutan jalan tersebut merupakan badan ad hoc yang berfungsi sebagai wahana untuk menyinergiskan tugas pokok serta fungsi setiap instansi penyelenggara lalu lintas dan angkutan jalan dalam rangka menganalisis permasalahan, menjembatani, menemukan solusi, serta meningkatkan kualitas pelayanan, dan bukan sebagai aparat penegak hukum. ${ }^{17}$

Forum lalu lintas dan angkutan jalan tersebut mempunyai tugas melakukan koordinasi antar instansi penyelenggara yang memerlukan ke-

17 Andika Wijaya, Aspek Hukum Bisnis Transportasi Jalan Online, Cetakan Pertama, (Jakarta : Sinar Grafika, 2016), hlm. 202 dan 203. 
terpaduan dalam merencanakan dan menyelesaikan masalah lalu lintas dan angkutan jalan, sedangkan keanggotaan forum tersebut terdiri atas unsur pembina, penyelenggara, akademisi, dan masyarakat. Peran serta masyarakat tersebut, meliputi : ${ }^{18}$

a. Memberikan masukan kepada instansi pembina lalu lintas dan angkutan jalan dalam penyempurnaan peraturan perundang-undang an, pedoman dan standar teknis di bidang angkutan jalan;

b. Memantau pelaksanaan standar pelayanan angkutan umum yang dilakukan oleh perusahaan angkutan umum;

c. Melaporkan perusahaan angkutan umum yang melakukan penyimpangan terhadap standar pelayanan angkutan umum kepada instansi pemberi izin;

d. Memberikan masukan kepada instansi pembina lalu lintas dan angkutan jalan dalam perbaikan pelayanan angkutan umum; dan/atau

e. Memelihara sarana dan prasarana angkutan jalan, serta ikut menjaga keamanan, keselamatan, ketertiban, dan kelancaran angkutan jalan.

Peran serta masyarakat sebagaimana ketentuan Pasal 120 ayat (1) Peraturan Pemerintah Nomor 74 Tahun 2014 disampaikan kepada instansi pemerintah atau pemerintah daerah sesuai dengan tugas pokok dan fungsi instansi. Selanjutnya, pemerintah dan/ atau pemerintah daerah mempertimbangkan serta menindaklanjuti masukan dan pendapat yang disampaikan oleh masyarakat. Pengaturan dan ketentuan lebih lanjut mengenai peran serta masyarakat diatur dengan peraturan menteri. ${ }^{19}$

Pembuatan peraturan baru atau revisi atas peraturan lama tersebut harus dilakukan dengan melibatkan peran serta masyarakat. Tidak dapat ditolak fakta bahwa perusahaan transportasi jalan online yang telah ada dewasa ini telah membuka peluang kerja bagi masyarakat. Secara konstitusional, warga negara Indonesia berhak atas pekerjaan dan penghidupan yang layak bagi kemanusiaan [vide Pasal 27 ayat (2) UndangUndang Dasar Negara Republik Indonesia Tahun 1945]. ${ }^{20}$

Sesuai ketentuan Pasal tersebut, warga negara Indonesia berhak memilih pekerjaan yang layak baginya. Dalam hal ini, perusahaan transportasi jalan online telah turut memberikan solusi bagi masyarakat pencari kerja. Sebagai negara hukum sebagaimana ketentuan Pasal 1 ayat (3) UndangUndang Dasar Negara Republik Indonesia Tahun 1945, pemecahan masalah serta pro dan kontra di seputar perusahaan transportasi jalan online harus

\footnotetext{
${ }^{19}$ Ibid.

${ }^{20}$ Ibid., hlm. 203 dan 204.
} 
dilaksanakan sesuai dengan peraturan perundang-undangan yang berlaku. Di sini, peran serta masyarakat dalam pembuatan peraturan perundangundangan memiliki arti sangat penting dan bersifat fundamental.

Dengan melibatkan masyarakat, maka hukum telah mewujudkan nilai keadilan, yakni keadilan sosial yang berdasarkan Pancasila. Keadilan hanya bisa dipahami jika ia diposisikan sebagai keadaan yang hendak diwujudkan oleh hukum. Upaya untuk mewujudkan keadilan dalam hukum tersebut merupakan proses yang dinamis yang memakan banyak waktu. Upaya ini seringkali juga didominasi oleh kekuatan-kekuatan yang bertarung dalam kerangka umum tatanan politik untuk mengaktualisasikannya. ${ }^{21}$

Hukum nasional hanya mengatur keadilan bagi semua pihak, oleh karenanya keadilan di dalam perspektif hukum nasional adalah keadilan yang menserasikan atau menselaraskan keadilan-keadilan yang bersifat umum di antara sebagian dari keadilan-keadilan individu. Dalam keadilan ini lebih menitikberatkan pada keseimbangan antara hak-hak individu masyarakat dengan kewajibankewajiban umum yang ada di dalam kelompok masyarakat hukum.

${ }^{21}$ Carl Joachim Friedrich, Filsafat Hukum Perspektif Historis, (Bandung : Nusamedia, 2004), hlm. 239.
Begitu pula dalam pengaturan angkutan non-umum berbasis online, menjadi baik apabila kepentingan para pihak diakomodasikan. Pihak yang kontra harus meyakini bahwa sebagai sesama manusia memiliki hak yang sama untuk mendapatkan pekerjaan yang layak, dan bagi pemerintah harus lebih memahami keinginan rakyatnya, karena sudah menjadi tugas pemerintah untuk mensejahterakan rakyatnya sebagai perwujudan negara kesejahteraan.

\section{Simpulan dan Saran}

1. Simpulan

a. Upaya yang dilakukan pemerintah dalam taraf sinkronisasi harmonisasi peraturan terkait pengaturan angkutan umum berbasis online yang memiliki kewenangan di bidang legislasi, yakni dengan melakukan revisi dan mencabut peraturan yang mengatur angkutan nonumum berbasis online, yakni Keputusan Menteri Perhubungan Nomor : UM.302/ 1/21/Phb/ 2015, Peraturan Menteri Perhubungan Nomor 32 Tahun 2016, Peraturan Menteri Perhubungan Nomor 26 Tahun 2017, dan terakhir dengan menerbitkan Peraturan Menteri Perhubungan Nomor 108 Tahun 2017. Revisi dan pencabutan terhadap peraturan menteri tersebut dikarenakan masih terdapat beberapa pasal yang bertentangan dengan Undang-Undang Nomor 22 
Tahun 2009 dan UndangUndang Nomor UndangUndang Nomor 20 Tahun 2008;

b. Problematika dalam upaya pemerintah pusat dalam taraf sinkronisasi dan harmonisasi peraturan terkait pengaturan angkutan non-umum berbasis online adalah sering dilakukannya revisi dan pencabutan peraturan menandakan peraturan tersebut belum dapat berlaku secara efektif dan belum memberikan kepastian hukum. Selain itu, masih adanya demontrasi atau protes terhadap peraturan tersebut, maka peraturan tersebut belum dapat mewujudkan tujuan hukum yakni keadilan dan belum memberikan perlindungan hukum bagi para pihak. Solusi yang dapat dilakukan adalah : (i) pemerintah tidak tergesa-gesa dalam menerbitkan peraturan; (ii) mengeluarkan peraturan yang dapat dilaksanakan oleh pihak terkait; (iii) pemerintah lebih mengedepankan kepentingan masyarakat; (iv) mendasarkan pada asas musyawarah mufakat dalam membentuk peraturan; serta (v) terkait dengan ojek online, pengaturannya dapat diserahkan pada pemerintah daerah dengan pembentukan peraturan daerah. Peran serta masyarakat juga sangat penting dalam pembuatan peraturan baru atau revisi atas peraturan lama. Dengan melibatkan masyarakat, maka hukum telah mewujudkan nilai keadilan, yakni keadilan sosial yang berdasarkan Pancasila.

\section{Saran-saran}

a. Pemerintah tidak tergesagesa dalam mengeluarkan peraturan terkait dengan angkutan non-umum berbasis online karena untuk membentuk kualitas peraturan yang baik dan mewujudkan sistem transportasi yang berkualitas dibutuhkan waktu dan biaya;

b. Diperlukan peran aktif masyarakat dalam membantu pemerintah membentuk peraturan yang baik dan berkualitas dalam rangka membangun dan menjalankan sistem transportasi umum Indonesia yang diinginkan oleh masyarakat;

c. Bagi masyarakat seyogyanya dapat saling mendukung terhadap peraturan atau kebijakan yang diambil oleh pemerintah demi kemajuan, keadilan, dan kemanfaatan. Apabila ada pihak yang kurang menyetujui, dapat memberikan saran kepada pemerintah tanpa harus melakukan perbuatan yang merugikan pihak lainnya.

\section{Daftar Pustaka}

Buku-buku :

Andika Wijaya, 2016, Aspek Hukum Bisnis Transportasi Jalan 
Online, Cetakan Pertama, Sinar Grafika, Jakarta.

Carl Joachim Friedrich, 2004 Filsafat Hukum Perspektif Historis, Nusamedia, Bandung.

Direktorat Hukum dan HAM, 2005, Kajian Harmonisasi Peraturan Perundang-Undangan Dalam Mendukung Pembang unan Nasional, Kementerian Negara Perencanaan Pembangunan Nasional/Bappenas, Jakarta.

Djauhari, 2008, Politik Hukum Negara Kesejahteraan Indonesia, Studi Tentang Kebijakan Regulasi dan Institusionalisasi Gagasan Kesejahteraan Sosial Ekonomi Masyarakat Nelayan di Jawa Tengah, Cetakan Kesatu, Unissula Press, Semarang.

Edi Setiadi dan Rena Yulia, 2010, Hukum Pidana Ekonomi, Edisi Pertama, Cetakan Pertama, Graha IImu, Yogyakarta.

Elly Erawati dkk. (Ed), 2011, Beberapa Pemikiran Tentang Pembangunan Sistem Hukum Nasional Indonesia Liber Amicorum Untuk Prof. Sunaryati Hartono, S.H., Citra Aditya Bakti, Bandung.

Ferry Irawan Febriansyah, 2016, Keadilan Berdasarkan Panca sila (Dasar Filosofis dan Ideologis Bangsa), Cetakan Pertama, Deepublish, Yogya karta.

Jawade Hafidz Arsyad dan Dian Karisma, 2018, Sentralisasi Birokrasi Pengadaan Barang \& Jasa Pemerintah, Cetakan
Pertama, Sinar Grafika, Jakarta.

Jhonny Ibrahim, 2011, Teori dan Metodologi Penelitian Hukum Normatif, Bayumedia, Malang.

Maria Farida Indrati S., 2013, IImu Perundang-Undangan 2, Pro ses dan Teknik Pembentukkannya 2, Cetakan Kelimabelas, Kanisius, Yogyakarta.

Miftah Thoha, 2012, Birokrasi Pemerintah Dan Kekuasaan Di Indonesia, Cetakan Pertama, Thafa Media, Yogyakarta.

Mukhlis Taib, 2017, Dinamika Perundang-Undangan Di Indonesia, Cetakan Kesatu, Refika Aditama, Bandung.

Mukti Fajar ND dan Yulianto Achmad, 2010, Dualisme Penelitian Hukum Normatif dan Empiris, Pustaka Pelajar, Yogyakarta.

Ridwan HR, 2006, Hukum Administrasi Negara, Edisi Pertama, Cetakan Kesatu, Raja Grafindo Persada, Jakarta.

Soerjono Soekanto, 1986, Pengantar Penelitian Hukum, Universitas Indonesia Press, Jakarta.

Yopie Morya Immanuel Patiro, 2012, Diskresi Pejabat Publik dan Tindak Pidana Korupsi, Cetakan Pertama, Keni Media, Bandung.

Internet:

Ukti BA, Negara Hukum Indonesia, sebagaimana diakses dalam http://uktibintiarifah.blogspot. co.id/2016/01/normal-0-falsefalse-false-in-x-none-x.html, 
